\title{
The Impact of Refugees on the Environment: The Case of Rwandan Refugees in Kivu, Zaïre
}

\author{
Shally B. Gachuruzi
}

\section{Précis}

En Juillet 1994, la région du Kivu, située à l'Est du Zaïre a accueilli plus $d^{\prime} u n$ million des réfugiés rwandais. Cette région est montagneuse et a un écosystème très fragile. A partir de sources secondaires, cet article analyse l'impact environnementale de la crise rwandaise dans cette partie du Zaïre. Il examine successivement le risque d'un désastre écologique à cause d'une déforestation excessive, la possibilité d'un conflit interethnique due d'abord au partage des ressources disponibles, et ensuite, à la compétition entre les réfugiés et la population autochtone.

\section{Introduction}

The Kivu region, where the majority of the Rwandan refugees are located is the most overpopulated region in Zaire. Its population is estimated at eight million and represents one fifth of the Zairrean population, almost the equivalent of the Rwandan population before the genocide of 1994 .

Moreover, Kivu has a fragile ecosystem that is being depleted by Rwandan refugees. Given that this region is already overpopulated, how can the organisations in charge of refugees reconcile their mandate with that of environmental protection? This is very important because a neglect of environmental factors can lead to further population displacement.

This paper attempts to analyse the environmental impact of the Rwandan crisis on Kivu, Zaïre. The following section provides an analysis of the risk of a potential ecological disaster, and its impact on the Kivu region, due to a prolonged presence of refugees in this region. The next section examines the

Dr. Shally Gachuruzi is a research associate at CRS, York University, with interests in forced migration, environment and development. impact of the Rwandan crisis on the local population, and considers the possibility of an interethnic confrontation in Kivu, due to the sharing of natural resources and the competition between refugees and indigenous Zaïreans.

\section{The Impact on Environment}

The impact of refugees on the environment in host countries is well known, even though studies on this issue are few. According to Lonergan $(1995,4)$ :

refugee movements tend to produce uncontrolled modifications which can lead to serious disruptions of ecological systems, and the ecological impact of mass movements can be very severe. Many nation's refugee influxes in the past decade have destabilised the local ecology and have caused a rapid depletion of scarce vegetation.

The settlement of refugees in rural areas entails deforestation to satisfy the need for wood for domestic purposes such as housing, heating, and cooking food. In 1990, "the UNHCR reported that there were approximately 15 million refugees in the world consuming an estimated 13 million metric tons of fuelwood a year" (Helin 1990, 1).

The following testimony collected by Lassailly $(1994,12)$ from a Zambian peasant in the Ukwimi locality illustrates well the ecological disaster which refugees can cause in host countries:

they chop down the trees we worship, they chop down the very old trees along the streams in order to extend their gardens when these trees helped prevent evaporisation with their shade. They collect all bamboo and reeds growing at one place, they light bush fires.

In addition to deforestation, two others types of environmental problems associated with refugees are land deg- radation and water contamination. Table 1 below summarizes the environmental problems in host countries related to mass movements of people.

The problem is felt most acutely in overpopulated countries with fragile ecosystems. This is presently the case in North Kivu, Zaire which is contending with the Rwandan refugee flux.

\section{Rwandan Refugees in Kivu}

The Kivu region has an international reputation in nature conservation. The Kahuzi Biega national park is located in South Kivu, which is home to mountain gorillas, many others animal species and diverse vegetation. The North Kivu region possesses one of the biggest parks in the world: the national park of Virunga. The reputation of these parks is due to the variety of species that cannot found anywhere else in the world.

In Kivu, deforestation is neither structured nor controlled. All cutting is thought to boost the value of the land, and is thus profitable to all the members of the community. There is an urgent need for studies of appropriate forms of land use and the development of agricultural methods, construction and other land uses.

The refugee camps of Katale and Kibumba are located within one kilometer of Virunga National Park. Even though there are no instances of wood cutting for construction, local journals indicate that the tourist authorities who manage the park complain about other illegal activities such as poaching and excessive collection of wood.

Research done by the UNDP (1994 24) on the environmental impact of the Rwandan refugees in Kivu concluded that:

19,090 personnes en moyenne utilisaient 20 pistes pour collecter chaque jour des produits forestiers. $57.5 \%$ de 
tout le bois collecté étaient verts, $35.9 \%$ du bois mort et $6.7 \%$ de la paille. Toutes les observations indiquent que le pourcentage du bois vert augmente sans cesse. 406 tonnes de bois étaient transportés chaque jour au camp par les 20 pistes. Il faut noter que les pertes de forêt observées ne concernent que les principales pistes du seul camp de Kibumba. Les estimation préliminaires de la perte totale de bois de tous les camps situés tout près ou à l'intérieur du Parc National des Virunga sont de 7,000 à $10,000 \mathrm{~m}$ par jour. $\mathrm{Vu}$ sous tous les angles, ce taux journalier de déboisement est tout simplement ahurissant.

This quotation means that, " 19,090 people were using 20 pathways everyday to collect forest products; $57.5 \%$ of woods collected were greens, $35.9 \%$ were dry and $6.7 \%$ were leaves. All observations show that the percentage of green woods is increasing. The preliminary estimates of wood loss are between $7,000.00 \mathrm{~m}$, and 10,000.00 m daily." Unfortunately, this study did not address the consequences of deforestation on wild life.

Excessive deforestation in a mountainous region results in erosion. According to local journals, Bukavu, one of the cities where the Rwandan refugees are located, must contend with extensive erosion due to deforestation. This has caused many deaths and the destruction of many houses. UNDP $(1994,27)$ research supports this assessment:

si l'on peut observer l'érosion dans et autour des camps des réfugiés à Goma, le probleme est réellement grave, et même critique, dans les camps autour de la ville de Bukavu, lesquels sont souvent situés sur des pentes raides et sur un sol alluvionnaire. L'absence de terrasses et de caniveaux de drainage appropriés ainsi que la destruction presque totale de la végétation sur ces pentes par des réfugiés entraînent érosion sévère et la formation des ravins qui s'approfondissent toujours après chaque forte pluie. Des glissements de terrain graves ont déjà été observés à Bukavu. A titre d'exemple, la route principale qui mène à l'aéroport de Bukavu étaient ferée pour quelques jours suite aux avalanches provenant des camps des réfugiés. L'hebdomadaire le Phare a rapporté dans sa livraison du 28 Octobre 1994 que plus de 100 personnes ont trouvé la mort à Kibange, à Bukavu, à la suite des pluies torrentielles du 21 Octobre. L'article a épinglé que l'absence des arbres sur la colline avait intensifié l'inondation et avait contribué à l'érosion sévère, l'un et l'autre ayant provoqué l'écroulement des douzaines des maisons.
This translates "as we can observe in and around the refugee camps in Goma, the problem is really serious, and even critical in and around the refugee camps in Bukavu city, located in a mountain area. Lack of appropriate terraces and the destruction of almost all vegetation by the Rwandan refugees caused erosions which destroyed many houses."

In many cases, the deforestation led to secondary problems both for the refugees and other aspects of the ecosystem. According to Jacobson (1994, 6), "the loss of browsing area, flora and fodder for domesticated herds and wild fauna leads to disruption of the natural food chain and potential eradication of species and fragile ecosystems in marginal areas. Similarly, faster runoff of rain water leads to a decrease in ground water replenishment, increased rates of silting in rivers and irrigation systems, and greater potential for flooding in catchment zones of formerly forested areas."

Another negative impact of the presence of the Rwandan refugees in Zaire, is the problem linked to the sharing of natural resources and the competition between refugees and the local population.

\section{Table 1: The Environmental Problems Experienced in Host Countries}

\section{Land Use}

Land degradation as a result of overgrazing and inappropriate farming methods

In camps, solid waste accumulation

\section{Long-term Implications}

Reduction in fertile arable land, desertification; soil desertification, soil erosion and pollution

Compromised health from sanitation-related diseases

Threats to food security from reduced agricultural productivity.

\section{Natural Resources}

Deforestation from overcutting of trees

Resource depletion from increased use of forest biomass; Threats to forest reserves from population encroachment

\section{Water Systems}

Reduction in water quality and quantity from over use of boreholes, oases

Source. Karen Jacobson(1994, 5). "The Impact of Refugees on the Environment: A Review on the Evidence?" 


\section{The Sharing of Natural Resources and the Competition between Refugees and Native Population}

The relationship between Hutus and Tutsis in Zaïre is very good. In general though, relationships between host governments and refugees tend to be fraught with difficulty.

La réinsertion de nouvelles entités villageoises dans un tissu social préexistant entraîne des profondes perturbations dans les équilibres existants entre les communautés humaines et entre ces dernières et l'espace. (Gachuruzi 1994, 24)

Translated this means that "the resettlement of the new villagers in a preexisting social fabric results in deep perturbations in the present equilibrium between the human communities, as well as between human communities and the space."

With respect to the Kivu population, it is difficult to create solidarity links between the refugees and the local population in accordance with the traditional model. Indeed, the sharing of available natural resources, such as trees, wild fruits, animals and fish has brought about an antagonistic relationship between the two groups. In addition, the differentiation of income between them has led to bitterness, and even open conflict.

The survival of the population depends on living in equilibrium with its natural surroundings. When natural resources are exploited, they can no longer support the population. Spitteler $(1993,2)$ writes: "food derived from woodland habitat, particularly important in draught prone areas such as Ukwimi where woodland food is a "buffer" against the famine, is becoming increasingly difficult to find" due to the concentration of refugees.

Spitteler's observation is similar to what is happening in Kivu, Zaïre. The peasants of Kivu draw their income from selling dry wood or charcoal. The selling of charcoal is a flourishing industry in the Great Lake Region. With a scarcity of wood, due to the concentration of refugees in the region, peasant's incomes have declined. They can no longer afford to buy meat, fish, or other commodities which they cannot cultivate.

According to Sullivan $(1992,20)$, "competition and the resultant shortage of gathered products affect local population incomes through reducing the availability of these products for sale and has generally a negative impact on diet and general wellbeing."

Moreover, basic goods have become increasingly rare and expensive. This is due not only to inflation, but also to the increasing scarcity of provisions. Many of the Rwandans came to Zaïre with substantial funds and bought Zaïrean homes and businesses. The refugees attend local schools and are treated in local hospitals; they even own farmland and parks.

Kengo wa Dondo, the Prime Minister of Zaïre, asserted that the refugees, with aid from the UN and private groups, are now better off than the local Zairean population. He warned that unless something is done, Zairean frustrations could turn into xenophobia.

Concerning the competition between the indigenous population and the refugees, Lassailly $(1994,16)$ provides this testimony from Zambia:

We understand that refugees had nothing when they arrived here and they should be helped and assisted, and we agreed to give them land to feed them. But we see that now many refugees make a lot of profit from our land. They are now growing tobacco, sunflowers and vegetables and they are provided with seeds and fertilizers when we get nothing.

In a similar manner, the competition between Zaireans and Rwandan refugees may directly and indirectly stir up people's emotions, leading to the collapse of the fragile peace between Zaïrean Banyarwandas and other ethnic groups.

The danger of violent conflict in Kivu, coupled with the prospect of ecological disaster due to the continued presence of the Rwandan refugees, may lead to another cycle of population displacement. All these environmental problems stress the need to generate interest in the search for new forms of intervention and development strategies in order to adequately meet the challenges of the political and environmental impact of the Rwandan crisis.

\section{Conclusion}

The long stay of the Rwandan refugees in the Great Lakes Region has political consequences in Burundi and socioeconomic and environmental impacts in Zairre. In both countries, there is the risk of an ensuing regional crisis that could lead to another wave of population displacement with disasterous effect on the people and the environment. It is contented that peace in this region, which is possible only with the will of the political leadership of the region, and the health of its environment depend on the repatriation of the Rwandan refugees.

\section{References}

Gachuruzi, B. Shally. 1994. "Le rapatriement des réfugiés rwandais: un véritable dilemme." Refuge, Vol. 14, No. 5, 21-25.

Helin, William. 1990. "Somalia: Trees and Refugees." Refugees, September.

Jacobson, J. 1988. "Environmental Refugees: A Yardstick of Hability." Washington, D.C.: Worldwatch Institute.

Jacobson, Karen. 1994. "The Impact of Refugees on the Environment: A Review of the Evidence." Washington, D.C.: The Refugee Policy Group (RPG).

Lassailly, Véronique. 1994. “Scheme-settled refugees and agro-ecological impact on hosts' environment: A field report from an agricultural settlement in Zambia, Ukwimi." Toronto: Centre for Refugee Studies, York University.

Lonergan, Steve. 1995. "Population Movements and the Environment." Refugee Studies Programme, Oxford, Issue 18.

Spitteler, M. 1993. "Balancing Woodland Resources Use Needs with Environmental Needs: A Case Study Of Ukwimi Refugee Settlement, Zambia." Refugee Studies Rrogramme, Oxford.

Sullivan, Sian. 1992. "Utilisation of, and ecological impact on, wild resources by Mozambican refugees and local Zambians at Ukwimi refugee settlement, Zambia." London: University College.

UNDP. 1994. “Enquête sur l'impact environnementale des réfugiés rwandais au Kivu, Zaiire," Novembre. $\square$ 